\title{
Local people's perceptions as decision support for protected area management in Wolong Biosphere Reserve, China
}

\author{
Jianying $\mathrm{Xu}$, Liding Chen*, Yihe Lu, Bojie Fu \\ Key Lab of Systems Ecology, Research Center for Eco-Environmental Sciences, Chinese Academy of Sciences, \\ P.O. Box 2871, Beijing 100085, People's Republic of China
}

Received 21 January 2004; revised 15 May 2005; accepted 16 May 2005

Available online 9 September 2005

\begin{abstract}
This paper examines local people's knowledge, attitudes and perceptions towards Wolong Biosphere Reserve (WBR) and its management policies. Pertinent data were collected through a questionnaire survey and group discussions. This study revealed that local people's perceptions were affected by many factors, including education, gender, residence location, household size and acreage of land owned. Although most respondents had limited knowledge about WBR because of their absence in WBR management, they held a positive attitude towards WBR. An in-depth analysis of their attitudes and perceptions showed that two potential conflicts might affect biodiversity conservation and protected area management. One of them was the imbalance between the limited cropland holding and the oversupply of the labor force, and the other one was the increase in electricity price versus the decrease in economic incentives for the Natural Forest Protection Project. The study also revealed that relocation was considered unacceptable to most respondents. However, those residing far from the main road were willing to relocate more than those near the main road. Based on our studies, some recommendations are given for improvement of WBR management.
\end{abstract}

(C) 2005 Elsevier Ltd. All rights reserved.

Keywords: Local people; Perceptions; Management improvement; Wolong Biosphere Reserve

\section{Introduction}

The number of protected areas in China increased from 34 in 1978 to 1757 in 2002 (Liu et al., 2003), accounting for approximately 0.13 and $13.2 \%$ of the total area, respectively. In addition, an ambitious goal was set in China to increase the number of reserves to 1800 by 2010 and 2500 by 2050 (State Forestry Administration, 2001). China's reserves are mostly distributed in the remote and underdeveloped regions (Han, 2000), where about 60 million people are living, and more than $75 \%$ of them are peasants (Miao, 2000). The population density of most nature reserves exceeds 60 persons $\mathrm{km}^{-2}$ (Wu et al., 2002). As a consequence, the rapid growth of protected areas and huge

\footnotetext{
Abbreviation: WBR, Wolong Biosphere Reserve.

* Corresponding author. Tel.: + 861062943840 ; fax: + 861062943840.

E-mail addresses: xujianying@eyou.com (J. Xu), liding@mail.rcees. ac.cn (L. Chen), 1vyihe@163.com (Y. Lu), bfu@mail.rcees.ac.cn (B. Fu).

pressure from the human population have become a great challenge to protected area management in China. Management authorities try to exclude local people from the reserve, and impose compulsive regulations to restrict resource exploitation. However, most local people depend on the natural resources of the reserves either for their livelihood and survival or as their main economic alternatives. The conflicts between reserve managers and local people are thus exacerbated (Ouyang et al., 2002). Widespread and escalating people-park conflicts, in many cases, have caused damage to valuable habitats, ecosystems, flora and fauna that are supposed to be protected (Harkness, 1998; Coggins, 2000; Han, 2000).

Local people, especially those living in and around protected areas, have important and long-standing relationships with these areas. Their needs, aspirations and attitudes should be considered in protected area management. Otherwise, the long-term survival of protected areas will be jeopardized (McNeely, 1990). This calls for community participation and equality in decision-making processes (IUCN, 1993). However, such recognition has not been given much attention in China's protected area management 
(Han, 2000). Most research on China's protected areas tended to focus on flora and fauna and addressed problems from the perspective of reserve managers or governments (Han, 2000; Miao, 2000; Wu et al., 2002). This typical topdown management style has marginalized local people's benefits and paid little attention to the role of local participation in protected area planning, management, and decision-making (Harkness, 1998; Miao, 2000).

To improve protected area management, perceptions and attitudes of the participants need to be studied, which, as Sewell (1973) pointed out, will offer much promise and help to identify the problems and to recognize potential solutions for developing appropriate strategy. Also, the outcome of decision-making is affected considerably by the perceptions and attitudes of participants in the process (White, 1966). There is growing empirical evidence indicating that assessment of local responses toward protected areas is a crucial step in gathering information that can be incorporated into decision-making processes and lead to people-park conflict mitigation (Newmark et al., 1993; Fiallo and Jacobson, 1995; Ruchi, 1998; Streever et al., 1998; Gillingham and Lee, 1999; Trakolis, 2001; Jim et al., 2002; Rao et al., 2003). On the other hand, local people's perceptions are determined by their values and frames of reference (ecological, economic and ethnological/culture) which lead to differences in needs, perceptions and attitudes along the lines of their personal attributes. It has been recognized that many demographical factors, such as age, education, residence location, affluence and ethnic origin can significantly shape the attitudes of local people (Newmark et al., 1993; Fiallo and Jacobson, 1995; Mehta and Heinen, 2001; Jim et al., 2002; Bandara and Tisdell, 2003).

The general theme from these studies is that local people's perceptions of protected areas depend on their perceived cost and benefit from protected areas, their dependence on local resources, and their knowledge about protected area management. Because local people are not homogenous and do not share common norms, their interests and resource use patterns vary greatly at both the individual and household level. Disregarding their diversity would cause detrimental effects to local people and hinder the achievement of conservation and management objectives (Agrawal and Gibson, 1999; Geoghegan and Renard, 2002). Therefore, managers and planners of protected areas are required to identify and understand the different interests of individuals, assess their dynamics, and integrate the pertinent information into protected area management.

The rapid increase in the number of protected areas demands an overall improvement in protected area management. The aforementioned research is crucial to understanding the complexity involved in protected area management, to advance decision-making on conflict resolution, and to foster a sustainable development of protected areas in China. The neglect of the above research topics would result in ignorance of the human dimension in
China's protected area management. In this paper, this issue was addressed from local people's perspective to determine if socioeconomic and demographic factors are closely related to local people's knowledge and perceptions, as well as how the information can be fed back to the management of protected areas. Therefore we selected Wolong Biosphere Reserve (WBR), a flagship nature reserve for protecting Giant Panda in China, as our case study site to conduct the research. This is because: (1) WBR has been fragmented by local people's activities (Liu et al., 2001); and (2) three new forest policies were implemented recently, i.e. Switch from Fuelwood to Electricity, Conversion of Cultivated Land into Forests, and Natural Forest Protection Project, which are closely related to biodiversity conservation and local people's welfare. Hence, an assessment of local responses towards conservation and management was conducted. The overall objectives of this study were: (1) to discern and interpret local people's knowledge, attitudes and perceptions towards WBR and its conservation initiatives; (2) to examine the reactions of local people to various measures which could be implemented to mitigate human pressure; (3) to identify whether local people with different demographic characteristics have different aptitudes; and (4) to comment on ad hoc approaches for nature reserve management in WBR.

\section{The study area}

WBR is the largest among the 25 nature reserves in China designated for Giant Panda (Ailuropoda melanoleuca) conservation, a flagship species in China's biodiversity conservation. About 100 Giant Pandas are living in the study area, $10 \%$ of the total Giant Panda population in China. The reserve was established in 1963 with an area of $200 \mathrm{~km}^{2}$, and expanded to its current size of $2000 \mathrm{~km}^{2}$ in 1975. It was upgraded to a biosphere reserve of the reserve network of the Man and Biosphere Program of UNESCO in 1980. The reserve is located in Wenchuan County, Sichuan province, southwestern China $\left(102^{\circ} 2^{\prime}\right.$ to $103^{\circ} 24^{\prime} \mathrm{E}, 30^{\circ} 45^{\prime}$ to $31^{\circ} 25^{\prime} \mathrm{N}$ ) (Fig. 1). It is situated in the transition zone from the Chengdu plain to the Qinghai-Tibet plateau. Its diverse environment provides a home to biodiversity. Besides Giant Panda, 57 kinds of endangered animals and 24 rare species of plants are also accommodated, such as Golden Monkey (Rhinopithecus roxellanae) and the Dove Tree (Davidia involucrata Baillon).

The reserve is managed by the Administration Bureau of Wolong Nature Reserve, under which are two township governments: Wolong Township and Gengda Township. A total of 1097 households were in the reserve with a population of more than 4000 in 2002. Although the Han group is the vast majority in China, approximately $70 \%$ of the local people belong to three minorities: Tibetan, Chang, and Hui. There is only a main road connecting local people to the outside. Local people depend mainly on traditional 


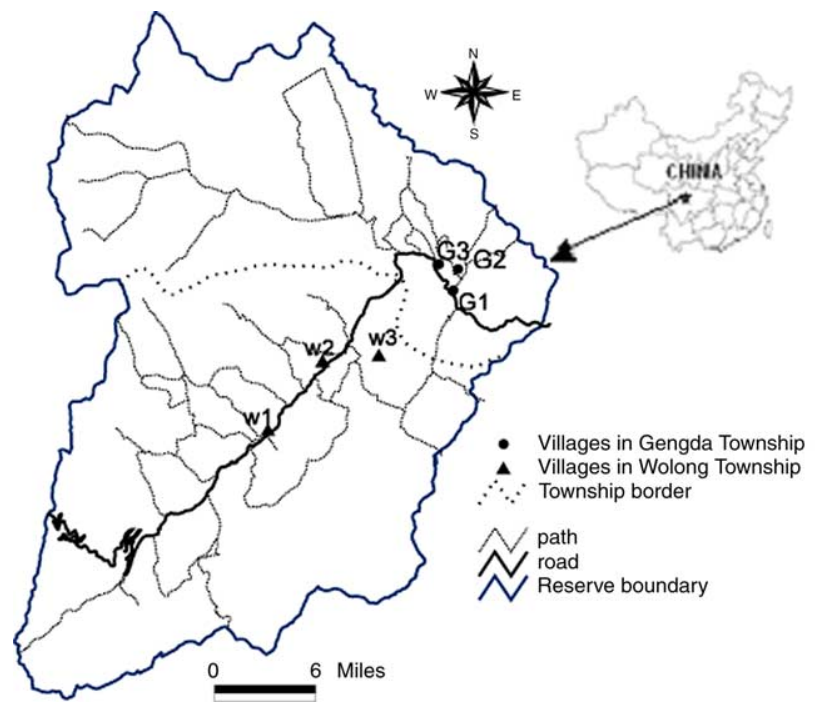

Fig. 1. Wolong Biosphere Reserve in Southwest China.

agriculture for subsistence in WBR. Maize, potato and cabbage are the main crops in the reserve, of which cabbage is the major source of income to local people. Besides local permanent inhabitants, many non-indigenous people work or live in the reserve, including businessmen, maintainers of hydropower stations, tourists, professional researchers, and managers of the reserve. Other employment opportunities in the reserve include housing construction, transportation, collection of Chinese herb medicine, and forest guarding and patrolling. But these employments are occasionally available. More detailed information about local people can be found in Fu's study (Fu et al., 2004).

The income of local people is currently affected by three governmental policies: Conversion of Cultivated Land into Forests, Natural Forest Protection Project, and Switch from Fuelwood to Electricity.

In $\mathrm{WBR}$, there are two types of cultivated land conversion. The first type is to convert cropland with a slope over $25^{\circ}$ to wood. The second one is to convert cropland into bamboo fields within $8 \mathrm{~m}$ on both sides of the main road. The former is emphasized in the Western Development Campaign by the Chinese Central Government and is carried out in many regions. The latter is the unique policy of WBR. To compensate for their loss of cropland, the farmers are subsidized with a certain amount of food and cash. However, those participating in the bamboo conversion receive more compensation, because lands close to the road are generally flat and have a good harvest. Almost all households were involved in slope cultivated land conversion, and only a few households were involved in bamboo land conversion.

The issue of 'energy for living' is a significant interest in WBR. Harvesting trees for fuelwood before 2001 led to panda habitat degradation and caused problems with the reserve's effectiveness in biodiversity conservation (Liu et al., 2001). In order to protect the forest and reduce local people's dependence on fuelwood, a policy prohibiting fuelwood collection and switching to electricity is being implemented. In WBR, energy was consumed for cooking (both human food and pig fodder), heating in winter and electrical appliances. Local people are reluctant to use electricity for cooking pig fodder and heating in winter because they are accustomed to wood burning stoves.

The intent of the Natural Forest Protection Project is to preserve natural forest and improve the ecological condition of the middle and upper reaches of the Yangtse River. In WBR, it can be viewed as a style of community-based conservation, which endeavors to promote local people's participation and realize co-management (Wolong Nature Reserve Administration Bureau, 2001). Under this program, each household is granted certain acreages of forest to manage. Economic incentives are rewarded to households based on their achievement in forest protection. Detailed regulations and duties are included in the contract between local households and the management authority, which are reviewed annually.

\section{Data collection and analysis}

\subsection{Data collection}

There are a total of 6 administrative villages in WBR, and all of them were selected for this study. A committee was set up for management in each village. According to the Fifth Population Census of China, the numbers of household in the three villages of Wolong Township are 147, 168, and 57; and in the three villages of Gengda Township are 208, 125, and 117. Among them, four villages (two in each township) are located near the main road; the other two are located far from the main road.

The research was carried out by means of a questionnaire, administered through personal interviews during July and August in 2003. One adult person ( $\geq 18$ years old) in each household was interviewed in his or her residence. All of them were permanent inhabitants. Although every individual, including children older than 5 years, played an active role in natural resource collection and production activities, only those over 18 years old were eligible to participate in government elections and decision-making based on national law. A total of 140 households were randomly selected from the 6 villages, and 137 households were successfully interviewed. Stratified sampling based on spatial distribution was employed to ensure proportional representation of households in the regions. To avoid potential bias, it was made clear to the participants that the investigation was for academic research without any affiliation with the management authority or any of the administrative setups. In addition, to avoid any influence of opinions from other members of the family, every attempt was made to hold a face-to-face interview with the participant privately. 
A questionnaire with both fix-response and open-ended questions was used. The fix-response questions and the possible alternative answers were read to interviewees, while the open ones were asked subsequently to gain an indepth understanding of their answers. The fix-response questions covered four areas relating to respondents': (1) knowledge of WBR, (2) attitudes toward WBR, (3) perceptions of benefits and losses brought by WBR, (4) reactions to five possible management policy scenarios (Table 1). In addition, some demographic information of the respondents (gender, education level, age, residence location) and household characteristics (household size, acreage of land owned, composition of household income) were also collected. Informal group discussions were held to probe deeper into the insights and perspectives of local people. Participants discussed issues covering forest

Table 1

Questions asked of local people to examine their responses

\begin{tabular}{ll}
\hline Questions & Responses \\
\hline Knowledge & \\
(1) Do you know the functions of WBR? & Yes/No \\
Could you briefly describe functions of the bio- & Open \\
sphere reserve? & \\
(2) Do you know the size of WBR? & Yes/No \\
(3) Do you know which zone your village is located? & Yes/No \\
Attitudes & \\
(4) Does the establishment of WBR improve your & Yes/No/No \\
lives? & opinion \\
Could you give reasons why your life is improved? & Open \\
(5) Are you satisfied that your village is included in & Yes/No/No \\
WBR? & opinion \\
Why are you satisfied with it? & Open \\
(6) Do you like the biosphere reserve? & Yes/No/No \\
Why do you like it? & opinion \\
(7) Are you satisfied with biosphere reserve's & Open \\
policy? & Yes/No/No \\
Which policy are you satisfied most and dissatisfied & opinion \\
most? & Open
\end{tabular}

most?

Perceptions

(8) Does the establishment of WBR bring you benefits?

Please indicate the level of your perceived benefits.

What are benefits the reserve brings to you?

(9) Does the establishment of WBR bring you

losses?

Please indicate the level of your perceived losses

What are losses the reserve brings to you?

Five possible management policy scenarios

(10) Relocation

(11) Working as migrant labor to obtain job outside WBR

(12) Engaging in tourism

(13) Continuation of agriculture but with cash crop replacement

(14) Continuation with the current system small/little

Open

Yes/No

High/medium/ small/little

Open

Agree/disagree/

No opinion

Agree/disagree/

No opinion

Agree/disagree/

No opinion

Agree/disagree/

No opinion

Agree/disagree/ resources and policies, villagers' expectations about development and employment.

\subsection{Data analysis}

Logistic regression analysis was used to assess the 'relative' importance of the various demographic and socioeconomic factors. For each input variable, a beta value (B), standard error (s.e), chi-square statistic $\left(\chi^{2}\right), p$ value and exp. Beta value $(\operatorname{Exp}(B))$ are presented in Tables 3-6. For the overall model, chi-square $\left(\chi^{2}\right)$, $p$-value and Nagelkerke $R$ Square $\left(R^{2}\right)$ are presented in Tables 3-6. Respondents' responses to the fix-response questions in Table 1 were recorded as binomial responses (yes/no, agree/ disagree) to develop dependent variables in the estimation of logistic regression models. The recording of respondents' responses was based on the assumption that a neutral response could indicate a potentially negative attitude (Newmark et al., 1993; Gillingham and Lee, 1999). Independent variables used in the estimation of the logistic regression model were as follows: gender (GEN), age (AGE), education (EDU), respondents' township affiliation (TOW), distance of respondents' residence from the main road (DIS), household size (HHS), acreage of land owned per capita in respondents' household (LAND). Survey data were analyzed with the aid of Statistical Package for the Social Sciences (SPSS) version 10.0 at the significance level of $p<0.05$.

\section{Results}

\subsection{Demographic variables}

A total of 59 women $(43 \%)$ and 78 men $(57 \%)$ were interviewed, of which $47 \%$ of the men and $41 \%$ of the women were in Wolong Township and the rest were in Gengda Township (Table 2). Respondents' ages were between 18 and 79 years old with an average of 40 .

Table 2

Demographic data and characteristics of the sample

No opinion

\begin{tabular}{lllll}
\hline $\begin{array}{l}\text { Character- } \\
\text { istics }\end{array}$ & Group & Wolong & Gengda & Total (\%) \\
\hline Gender & Females & 24 & 35 & $59(43.1 \%)$ \\
Age & Males & 37 & 41 & $78(56.9 \%)$ \\
& $<30$ years & 21 & 18 & $39(28.5 \%)$ \\
& 30-50 years & 23 & 39 & $62(45.2 \%)$ \\
Education & $>50$ years & 17 & 19 & $36(26.3 \%)$ \\
& $\leq$ Elemen- & 27 & 43 & $70(51.1 \%)$ \\
& tary school & & & \\
& Junior high & 25 & 21 & $46(33.6 \%)$ \\
& school & & & \\
& $\geq$ Senior & 9 & 12 & $21(15.3 \%)$ \\
& high school & & & \\
Distance & or college & & & $68(49.6 \%)$ \\
from road & Far & 34 & 34 & $69(50.3 \%)$ \\
\hline
\end{tabular}


The 31-50 year-old group was the largest one, followed by the 51-79 and 18-30 groups. With regard to education, about $19 \%$ of the respondents were illiterate, $32 \%$ educated to elementary school, $33 \%$ to junior high school, and $15 \%$ to senior high school or higher. As for the residence location, the respondents were distributed approximately equally, $50 \%$ of them dwelled in the villages far from the main road, the others close to the road. Household size varied from 2 to 10 members with a mean of 5.1 persons.

\subsection{Knowledge of local people about WBR}

Interviewees were asked about their knowledge relative to the biosphere reserve and its functional zonation (Table 1, Questions 1-3) that divided the whole reserve into three zones-core zone, buffer zone and experimental zone-to reconcile relationships between local people's needs and biodiversity conservation. Their answers and influencing factors are shown in Table 3. Almost all respondents (91.2\%) indicated that they knew the functions of WBR (Question 1). Protection of Giant Panda (Alluropoda melanoleuca) was mentioned mostly $(65.4 \%)$, followed by protection of wildlife $(40.5 \%)$, protection of forest (31\%) and protection of ecosystem and maintenance of ecological balance (14.3\%). Only a few people stated that the function was to prevent illegal deforestation and utilize nature resources reasonably (5\%), and to protect other animals, such as Golden Monkey (Rhinopithecus roxllanae) (2\%). About $84 \%$ of the interviewees were not aware of the size of
WBR. A majority (85\%) of the respondents had no knowledge about the WBR's functional zonation, as examined in Question 3.

Logistic regression results revealed that gender could be an important factor influencing local people's knowledge about WBR. It was found that males had more knowledge than females. Other observations included: (1) respondents affiliated with different townships had different levels of knowledge; (2) families with bigger household size had more knowledge; and (3) respondents with older age had more knowledge.

\subsection{Attitudes of local people toward WBR}

The attitudes of local people were evaluated in order to get a general impression of local people's reactions towards the biosphere reserve (Table 1, Questions 4-7). The results of the survey and logistic regression are presented in Table 4. About one-third $(35.8 \%)$ of the respondents admitted that their lives had been improved, but they attributed it to the reform of national policy, i.e. Reform and Opening to the Outside World, rather than the establishment of the reserve. Most respondents $(67.9 \%)$ were satisfied with the biosphere reserve and pleased $(66.4 \%)$ that their village was in WBR. The main reason for the satisfaction was that they had been there for generations and were used to the traditional life and physical environment. 42.3, 32.8 and $24.8 \%$ of the respondents showed positive, neutral and negative response to the reserve's policies, respectively.

Table 3

Respondents' knowledge about WBR and influencing factors

\begin{tabular}{|c|c|c|c|c|c|c|c|c|c|c|c|c|c|}
\hline \multirow{2}{*}{$\begin{array}{l}\text { Ques- } \\
\text { tions }\end{array}$} & \multirow[t]{2}{*}{ Answers } & \multirow[t]{2}{*}{ Wolong } & \multirow[t]{2}{*}{ Gengda } & \multirow[t]{2}{*}{ Total $(\%)$} & \multicolumn{5}{|c|}{ Variables $^{\mathrm{b}}$ in the equation } & \multicolumn{4}{|c|}{ Final logistic model } \\
\hline & & & & & & B & s.e. & $\chi^{2}$ & $p$ value & $\operatorname{Exp}(B)$ & $\chi^{2}$ & $p$ value & $R^{2}$ \\
\hline \multirow[t]{7}{*}{$\overline{(1)}$} & \multirow[t]{3}{*}{ Yes } & \multirow[t]{3}{*}{51} & \multirow[t]{3}{*}{74} & \multirow[t]{3}{*}{$125(91.2 \%)$} & DIS & -1.360 & 0.793 & 2.938 & 0.087 & 0.257 & \multirow[t]{7}{*}{35.144} & \multirow[t]{7}{*}{0.000} & \multirow[t]{7}{*}{0.428} \\
\hline & & & & & DIS & -4.275 & 1.179 & 13.148 & 0.000 & 0.014 & & & \\
\hline & & & & & TOW & 1.436 & 0.754 & 3.624 & 0.057 & 4.203 & & & \\
\hline & \multirow[t]{4}{*}{ No } & \multirow[t]{4}{*}{10} & \multirow[t]{4}{*}{2} & \multirow[t]{4}{*}{$12(8.8 \%)$} & GEN & -0.759 & 0.730 & 1.083 & 0.298 & 0.468 & & & \\
\hline & & & & & EDU & 0.001 & 0.030 & 0.002 & 0.968 & 1.001 & & & \\
\hline & & & & & AGE & -0.712 & 0.301 & 5.588 & 0.018 & 0.491 & & & \\
\hline & & & & & HHS & -0.672 & 1.070 & 0.395 & 0.530 & 0.510 & & & \\
\hline \multirow[t]{7}{*}{ (2) } & \multirow[t]{3}{*}{ Yes } & \multirow[t]{3}{*}{15} & \multirow[t]{3}{*}{7} & \multirow[t]{3}{*}{$22(16.1 \%)$} & DIS & -0.123 & 0.570 & 0.047 & 0.829 & 0.884 & \multirow[t]{7}{*}{36.349} & \multirow[t]{7}{*}{0.000} & \multirow[t]{7}{*}{0.353} \\
\hline & & & & & TOW & -1.271 & 0.558 & 5.193 & 0.023 & 0.281 & & & \\
\hline & & & & & GEN & 1.623 & 0.667 & 5.927 & 0.015 & 0.525 & & & \\
\hline & \multirow[t]{4}{*}{ No } & \multirow[t]{4}{*}{46} & \multirow[t]{4}{*}{69} & \multirow[t]{4}{*}{$115(83.9 \%)$} & EDU & -0.645 & 0.484 & 1.777 & 0.182 & 0.525 & & & \\
\hline & & & & & AGE & -0.060 & 0.021 & 8.132 & 0.004 & 0.942 & & & \\
\hline & & & & & HHS & -0.287 & 0.130 & 4.858 & 0.028 & 0.750 & & & \\
\hline & & & & & LAND & -0.725 & 0.749 & 0.937 & 0.333 & 0.484 & & & \\
\hline (3) & Yes & 12 & 8 & $20(14.6 \%)$ & DIS & 0.905 & 0.485 & 3.484 & 0.062 & 2.471 & 20.034 & 0.005 & 0.186 \\
\hline & & & & & TOW & -0.254 & 0.437 & 0.339 & 0.561 & 0.775 & & & \\
\hline & & & & & GEN & 0.921 & 0.469 & 3.854 & 0.050 & 2.511 & & & \\
\hline & & & & & EDU & -0.428 & 0.370 & 1.336 & 0.248 & 0.652 & & & \\
\hline & No & 49 & 68 & $117(85.4 \%)$ & AGE & 0.027 & 0.019 & 2.184 & 0.139 & 1.028 & & & \\
\hline & & & & & HHS & -0.106 & 0.119 & 0.790 & 0.374 & 0.899 & & & \\
\hline & & & & & LAND & 0.019 & 0.632 & 0.001 & 0.976 & 1.019 & & & \\
\hline
\end{tabular}

a See Table 1 for the list of these questions.

b DIS = Distance of respondents' residence from the main road; TOW, Respondents' township affiliation; GEN, Gender; EDU, Education; AGE, Age; HHS, Household size; LAND, Acreage of land owned per capita in respondents' household. 
Table 4

Respondents' attitudes towards WBR and influencing factors

\begin{tabular}{|c|c|c|c|c|c|c|c|c|c|c|c|c|c|}
\hline \multirow{2}{*}{$\begin{array}{l}\text { Ques- } \\
\text { tions }\end{array}$} & \multirow[t]{2}{*}{ Answers } & \multirow[t]{2}{*}{ Wolong } & \multirow[t]{2}{*}{ Gengda } & \multirow[t]{2}{*}{ Total $(\%)$} & \multicolumn{5}{|c|}{ Variables $^{\mathrm{b}}$ in the equation } & \multicolumn{4}{|c|}{ Final logistic model } \\
\hline & & & & & & B & s.e & $\chi^{2}$ & $p$ value & $\operatorname{Exp}(B)$ & $\chi^{2}$ & $p$ value & $R^{2}$ \\
\hline \multirow[t]{7}{*}{ (4) } & \multirow[t]{2}{*}{ Yes } & \multirow[t]{2}{*}{23} & \multirow[t]{2}{*}{26} & \multirow[t]{2}{*}{$49(35.8 \%)$} & DIS & -0.203 & 0.403 & 0.253 & 0.615 & 0.817 & \multirow[t]{7}{*}{19.776} & \multirow[t]{7}{*}{0.006} & \multirow[t]{7}{*}{0.164} \\
\hline & & & & & TOW & 0.302 & 0.389 & 0.604 & 0.437 & 1.353 & & & \\
\hline & No & 12 & 18 & $30(21.9 \%)$ & GEN & 1.039 & 0.399 & 6.772 & 0.009 & 2.828 & & & \\
\hline & opinion & & & & EDU & -0.405 & 0.348 & 1.351 & 0.245 & 0.667 & & & \\
\hline & \multirow{3}{*}{ No } & \multirow{3}{*}{26} & \multirow[t]{3}{*}{32} & \multirow{3}{*}{$58(42.3 \%)$} & $\mathrm{AGE}$ & -0.017 & 0.015 & 1.306 & 0.253 & 0.983 & & & \\
\hline & & & & & HHS & -0.281 & 0.111 & 6.447 & 0.011 & 0.755 & & & \\
\hline & & & & & LAND & -0.093 & 0.509 & 0.033 & 0.855 & 0.911 & & & \\
\hline \multirow[t]{7}{*}{ (5) } & \multirow[t]{2}{*}{ Yes } & \multirow[t]{2}{*}{41} & \multirow[t]{2}{*}{52} & \multirow[t]{2}{*}{$93(67.9 \%)$} & DIS & 0.177 & 0.375 & 0.223 & 0.637 & 1.194 & \multirow[t]{7}{*}{10.463} & \multirow[t]{7}{*}{0.164} & \multirow[t]{7}{*}{0.088} \\
\hline & & & & & TOW & 0.303 & 0.369 & 0.674 & 0.412 & 1.354 & & & \\
\hline & No & 8 & 17 & $25(18.2 \%)$ & GEN & 0.327 & 0.368 & 0.791 & 0.374 & 1.387 & & & \\
\hline & opinion & & & & EDU & -0.440 & 0.349 & 1.590 & 0.207 & 0.644 & & & \\
\hline & No & 12 & 7 & $19(13.9 \%)$ & AGE & 0.017 & 0.014 & 1.402 & 0.236 & 1.017 & & & \\
\hline & & & & & HHS & -0.171 & 0.110 & 2.420 & 0.120 & 0.843 & & & \\
\hline & & & & & LAND & -0.871 & 0.489 & 3.174 & 0.075 & 0.418 & & & \\
\hline (6) & Yes & 40 & 51 & $91(66.4 \%)$ & DIS & -0.194 & 0.372 & 0.271 & 0.602 & 0.824 & 12.895 & 0.075 & 0.107 \\
\hline & & & & & TOW & 0.305 & 0.365 & 0.698 & 0.403 & 1.357 & & & \\
\hline & No & 10 & 17 & $27(19.7 \%)$ & GEN & 0.277 & 0.368 & 0.569 & 0.451 & 1.320 & & & \\
\hline & opinion & & & & EDU & -0.683 & 0.360 & 3.606 & 0.058 & 0.505 & & & \\
\hline & No & 11 & 8 & $19(13.9 \%)$ & $\mathrm{AGE}$ & 0.023 & 0.014 & 2.728 & 0.099 & 1.023 & & & \\
\hline & & & & & HHS & -0.019 & 0.100 & 0.038 & 0.846 & 0.981 & & & \\
\hline & & & & & LAND & -0.225 & 0.466 & 0.232 & 0.630 & 0.799 & & & \\
\hline (7) & Yes & 22 & 36 & $58(42.3 \%)$ & DIS & -0.194 & 0.377 & 0.266 & 0.606 & 0.823 & 17.672 & 0.014 & 0.143 \\
\hline & & & & & TOW & 0.817 & 0.369 & 4.908 & 0.027 & 2.263 & & & \\
\hline & No & 19 & 26 & $45(32.8 \%)$ & GEN & 1.106 & 0.372 & 8.823 & 0.003 & 3.023 & & & \\
\hline & opinion & & & & EDU & -0.168 & 0.327 & 0.263 & 0.608 & 0.846 & & & \\
\hline & No & 49 & 68 & $117(85.4 \%)$ & AGE & -0.007 & 0.014 & 0.291 & 0.589 & 0.993 & & & \\
\hline & & & & & HHS & 0.092 & 0.116 & 0.637 & 0.425 & 1.097 & & & \\
\hline & & & & & LAND & 0.304 & 0.477 & 0.406 & 0.524 & 1.355 & & & \\
\hline
\end{tabular}

a See Table 1 for the list of these questions.

b DIS = Distance of respondents' residence from the main road; TOW, Respondents' township affiliation; GEN, Gender; EDU, Education; AGE, Age; HHS, Household size; LAND, Acreage of land owned per capita in respondents' household.

The follow-up question indicated that they were satisfied most with the policy of Natural Forest Protection Project and dissatisfied most with the policy of Switch from Fuelwood to Electricity.

Of the factors influencing the attitudes of respondents, gender was identified as a significant predictor of responses. Supportive attitudes for the reserve and its policies were positively correlated with male respondents. The respondents in larger households agreed that the establishment of WBR had improved their lives. The respondents in Wolong Township were more dissatisfied with WBR's policy than those in Gengda Township.

\subsection{Perceptions of local people towards WBR}

The perceptions of local people were examined based on questions 8-9 (Table 1). The results of the survey and logistic regression analysis are shown in Table 5. In terms of benefits, $72 \%$ of the respondents considered that the establishment of WBR had brought them benefits, $27 \%$ considered no benefit. As to the level of perceived benefits, $12.8 \%$ of them perceived it to be high, $25.6 \%$ to be medium, 41.9 and $19.8 \%$ to be small and little, respectively $(n=99)$.
The logistic regression analysis indicated that respondents with higher education level and more household member were more likely to perceive benefits. The Natural Forest Protection Project was considered the largest benefit by almost all respondents because it could bring a certain amount of income to them every year. The policy of Conversion of Cultivated Land into Forests was listed as the second benefit because it could relieve the local people from agricultural labor while getting a subsidy for living.

As for the perceived losses, $62 \%$ of the respondents perceived that the establishment of WBR had brought them losses, and $38 \%$ perceived no losses. As to the level of perceived losses, some $24.3 \%$ of them thought the losses to be high, $33.8 \%$ to be medium, $27.6 \%$ to be small and $5 \%$ to be little $(n=85)$. Logistic regression analysis indicated that the more land owned by the respondents, the more losses were perceived. In addition, the respondents' education level also had an association with their perceived losses. More respondents with higher education level claimed losses than those with lower education level. Switch from fuelwood to electricity, restrictions on wood resources utilization, and no compensation for destroyed fields by wild boar were considered three main losses by most 
Table 5

Respondents' perceptions towards WBR and influencing factors

\begin{tabular}{|c|c|c|c|c|c|c|c|c|c|c|c|c|c|}
\hline \multirow{2}{*}{$\begin{array}{l}\text { Ques- } \\
\text { tions }\end{array}$} & \multirow[t]{2}{*}{ Answers } & \multirow[t]{2}{*}{ Wolong } & \multirow[t]{2}{*}{ Gengda } & \multirow[t]{2}{*}{ Total $(\%)$} & \multicolumn{5}{|c|}{ Variables $^{\mathrm{b}}$ in the equation } & \multicolumn{4}{|c|}{ Final logistic model } \\
\hline & & & & & & $\mathrm{B}$ & s.e & Wald & $p$ value & $\overline{\operatorname{Exp}(B)}$ & $\chi^{2}$ & $p$ value & $R^{2}$ \\
\hline \multirow[t]{7}{*}{$(8)$} & \multirow[t]{3}{*}{ Yes } & \multirow[t]{3}{*}{46} & \multirow[t]{3}{*}{53} & \multirow[t]{3}{*}{$99(72.3 \%)$} & DIS & -0.141 & 0.403 & 0.123 & 0.726 & 0.868 & \multirow[t]{7}{*}{35.984} & \multirow[t]{7}{*}{0.000} & \multirow[t]{7}{*}{0.273} \\
\hline & & & & & TOW & 0.539 & 0.396 & 1.847 & 0.174 & 1.714 & & & \\
\hline & & & & & GEN & 0.601 & 0.387 & 2.412 & 0.120 & 1.824 & & & \\
\hline & \multirow[t]{4}{*}{ No } & \multirow[t]{4}{*}{15} & \multirow[t]{4}{*}{23} & \multirow[t]{4}{*}{$38(27.7 \%)$} & EDU & -1.241 & 0.400 & 9.633 & 0.002 & 0.289 & & & \\
\hline & & & & & AGE & -0.002 & 0.015 & 0.017 & 0.897 & 0.998 & & & \\
\hline & & & & & HHS & -0.487 & 0.138 & 12.522 & 0.000 & 0.615 & & & \\
\hline & & & & & LAND & -0.616 & 0.503 & 1.496 & 0.221 & 0.540 & & & \\
\hline \multirow[t]{7}{*}{ (9) } & \multirow[t]{3}{*}{ Yes } & \multirow[t]{3}{*}{37} & \multirow[t]{3}{*}{48} & \multirow[t]{3}{*}{$85(62 \%)$} & DIS & 0.121 & 0.371 & 0.106 & 0.745 & 1.128 & \multirow[t]{7}{*}{12.999} & \multirow[t]{7}{*}{0.072} & \multirow[t]{7}{*}{0.107} \\
\hline & & & & & TOW & 0.415 & 0.361 & 1.324 & 0.250 & 1.515 & & & \\
\hline & & & & & GEN & -0.233 & 0.364 & 0.409 & 0.522 & 0.792 & & & \\
\hline & \multirow[t]{4}{*}{ No } & \multirow[t]{4}{*}{24} & \multirow[t]{4}{*}{28} & \multirow[t]{4}{*}{$52(38 \%)$} & EDU & -0.687 & 0.343 & 4.016 & 0.045 & 0.503 & & & \\
\hline & & & & & AGE & -0.017 & 0.014 & 1.445 & 0.229 & 0.983 & & & \\
\hline & & & & & HHS & -0.096 & 0.103 & 0.853 & 0.356 & 0.909 & & & \\
\hline & & & & & LAND & -1.223 & 0.508 & 5.803 & 0.016 & 0.294 & & & \\
\hline
\end{tabular}

a See Table 1 for the list of these questions

b DIS = Distance of respondents' residence from the main road; TOW, Respondents' township affiliation; GEN, Gender; EDU, Education; AGE, Age; HHS, Household size; LAND, Acreage of land owned per capita in respondents' household.

respondents. Among them, switch from fuelwood to electricity was considered the primary one because of the increased cost of electricity in recent years.

\subsection{Reactions of local people to five possible management policy scenarios in WBR}

Questions 10-14 were designed to evaluate how local people react to five possible management scenarios that were likely to be implemented in the study area to diversify local people's choice and thus to mitigate human pressure on the biosphere reserve. In this study, the respondents were asked if the wildlife in the biosphere reserve was threatened due to human activities and some measures were required for wildlife protection, what would be the best one. The respondents' inclinations and influencing factors are shown in Table 6. Respondents with lower age and more land in the household preferred to accept the solution of 'continuation of agriculture but with cash crops replacement', which was accepted by $70 \%$ of respondents. Some $69 \%$ of respondents gave an 'agree' answer to the option of engaging in tourism, male respondents in larger households preferred this case.

More than $56 \%$ of respondents expressed a positive reaction to the case 'working as migrant labor to obtain job opportunity outside the biosphere reserve'. Concerning the policy of 'relocation' and 'continuation with the current system', 59 and $58 \%$ of respondents, respectively, disagreed, whereas 29 and $32 \%$ respondents respectively, agreed with the two cases. According to the logistic regression analysis, respondents residing far from the main road were more agreeable to relocation than those close to the road and respondents with more acreage of land owned per capita in the household preferred to continue with the current system.

\section{Discussion}

\subsection{Limited knowledge implying lack of local participation}

The research findings regarding local people's limited knowledge about WBR and its functional zonation should be paid attention by WBR management. By contrast, respondents living in Wolong Township knew more than those in Gengda Township. This can be attributed to the fact that Wolong Administration Bureau is located in Wolong Township, where local people have more opportunities to have contact with the bureau and obtain information. The gender discrepancy in knowledge could relate to the way of conveying information to local people. In WBR, as well as in other places of China, rural inhabitants receive information mainly through a village committee, which aims at male heads of households. The gender difference in attitude towards WBR's policy also supports this observation. Older interviewees have more experience and longer life history in the reserve, so they know better than others about the size of the reserve.

The limited knowledge of local people about WBR implies a poor public participation and communication mechanism in the reserve management. Another possible explanation was attributed to household size. It is possible that respondents with more family members tend to have more opportunities to interact with others to acquire information. Noticeably, functional zonation, which is a key strategy to create a spatial compromise so that local people can continue to meet their livelihood needs while protecting key species and habitats, is unknown to most interviewees. The fact that local participation is limited and almost no real equality or mutual benefit exists between protected area management authorities and local inhabitants is a common problem in the reserve management in China 
Table 6

Respondents' reactions to five possible management policy scenarios and influencing factors

\begin{tabular}{|c|c|c|c|c|c|c|c|c|c|c|c|c|c|}
\hline \multirow{2}{*}{$\begin{array}{l}\text { Ques- } \\
\text { tions }\end{array}$} & \multirow[t]{2}{*}{ Answers } & \multirow[t]{2}{*}{ Wolong } & \multirow[t]{2}{*}{ Gengda } & \multirow[t]{2}{*}{ Total $(\%)$} & \multicolumn{5}{|c|}{ Variables ${ }^{\mathrm{b}}$ in the equation } & \multicolumn{4}{|c|}{ Final logistic model } \\
\hline & & & & & & $\mathrm{B}$ & s.e & $\chi^{2}$ & $\overline{p \text { value }}$ & $\overline{\operatorname{Exp}(B)}$ & $\chi^{2}$ & $p$ value & $R^{2}$ \\
\hline \multirow[t]{7}{*}{ (10) } & \multirow[t]{2}{*}{ Agree } & \multirow[t]{2}{*}{21} & \multirow[t]{2}{*}{19} & \multirow[t]{2}{*}{$40(29.2 \%)$} & DIS & -1.816 & 0.462 & 15.437 & 0.000 & 0.163 & \multirow[t]{7}{*}{19.798} & \multirow[t]{7}{*}{0.006} & \multirow[t]{7}{*}{0.172} \\
\hline & & & & & TOW & -0.411 & 0.401 & 1.051 & 0.305 & 0.663 & & & \\
\hline & \multirow[t]{2}{*}{ No opinion } & \multirow[t]{2}{*}{6} & \multirow[t]{2}{*}{10} & \multirow[t]{2}{*}{$16(11.7 \%)$} & GEN & 0.505 & 0.422 & 1.429 & 0.232 & 1.657 & & & \\
\hline & & & & & EDU & -0.052 & 0.368 & 0.020 & 0.887 & 0.949 & & & \\
\hline & \multirow[t]{3}{*}{ Disagree } & \multirow[t]{3}{*}{34} & \multirow[t]{3}{*}{47} & \multirow[t]{3}{*}{$81(59.1 \%)$} & AGE & 0.013 & 0.016 & 0.641 & 0.423 & 1.013 & & & \\
\hline & & & & & HHS & 0.027 & 0.118 & 0.053 & 0.818 & 1.028 & & & \\
\hline & & & & & LAND & 0.934 & 0.578 & 2.610 & 0.106 & 2.543 & & & \\
\hline \multirow[t]{7}{*}{ (11) } & Agree & 35 & 42 & $77(56.2 \%)$ & DIS & -0.170 & 0.356 & 0.227 & 0.634 & 0.844 & 11.845 & 0.106 & 0.105 \\
\hline & & & & & TOW & 0.045 & 0.347 & 0.017 & 0.898 & 1.046 & & & \\
\hline & No opinion & 22 & 32 & $54(39.4 \%)$ & GEN & 0.486 & 0.351 & 1.922 & 0.166 & 1.626 & & & \\
\hline & & & & & EDU & -0.192 & 0.318 & 0.363 & 0.547 & 0.826 & & & \\
\hline & Disagree & 4 & 2 & $6(4.4 \%)$ & AGE & 0.010 & 0.013 & 0.583 & 0.445 & 1.010 & & & \\
\hline & & & & & HHS & 0.007 & 0.096 & 0.005 & 0.941 & 1.007 & & & \\
\hline & & & & & LAND & 0.292 & 0.448 & 0.424 & 0.515 & 1.339 & & & \\
\hline (12) & Agree & 45 & 50 & $95(69.3 \%)$ & DIS & -0.266 & 0.402 & 0.436 & 0.509 & 0.767 & & & \\
\hline & & & & & TOW & 0.006 & 0.399 & 0.000 & 0.988 & 1.006 & 25.600 & 0.001 & 0.209 \\
\hline & No opinion & 6 & 6 & $12(8.8 \%)$ & GEN & 1.474 & 0.407 & 13.134 & 0.000 & 4.366 & & & \\
\hline & & & & & EDU & -0.205 & 0.376 & 0.298 & 0.585 & 0.815 & & & \\
\hline & Disagree & 10 & 20 & $30(21.9 \%)$ & AGE & 0.024 & 0.015 & 2.450 & 0.118 & 1.024 & & & \\
\hline & & & & & HHS & -0.269 & 0.126 & 4.575 & 0.032 & 0.764 & & & \\
\hline & & & & & LAND & -0.963 & 0.526 & 3.351 & 0.067 & 0.382 & & & \\
\hline (13) & Agree & 46 & 50 & $96(70.1 \%)$ & DIS & 0.065 & 0.398 & 0.027 & 0.870 & 1.067 & 15.292 & 0.032 & 0.130 \\
\hline & & & & & TOW & -0.491 & 0.394 & 1.550 & 0.213 & 0.612 & & & \\
\hline & No opinion & 10 & 22 & $32(23.4 \%)$ & GEN & 0.684 & 0.393 & 3.034 & 0.082 & 1.982 & & & \\
\hline & & & & & EDU & 0.370 & 0.355 & 1.085 & 0.298 & 1.447 & & & \\
\hline & Disagree & 5 & 4 & $9(6.6 \%)$ & AGE & 0.033 & 0.015 & 4.845 & 0.028 & 1.033 & & & \\
\hline & & & & & HHS & -0.199 & 0.124 & 2.573 & 0.109 & 0.820 & & & \\
\hline & & & & & LAND & -1.178 & 0.532 & 4.893 & 0.027 & 0.308 & & & \\
\hline (14) & Agree & 21 & 23 & $44(32.1 \%)$ & DIS & 0.490 & 0.396 & 1.531 & 0.216 & 1.632 & 4.505 & 0.038 & 0.720 \\
\hline & & & & & TOW & -0.436 & 0.374 & 1.358 & 0.244 & 0.647 & & & \\
\hline & No opinion & 6 & 8 & $14(10.2 \%)$ & GEN & -0.666 & 0.382 & 3.044 & 0.081 & 0.514 & & & \\
\hline & & & & & EDU & 0.193 & 0.340 & 0.323 & 0.570 & 1.213 & & & \\
\hline & Disagree & 34 & 45 & $79(57.7 \%)$ & AGE & -0.015 & 0.014 & 1.066 & 0.302 & 0.985 & & & \\
\hline & & & & & HHS & 0.041 & 0.103 & 0.162 & 0.688 & 1.042 & & & \\
\hline & & & & & LAND & -1.033 & 0.499 & 4.293 & 0.038 & 0.356 & & & \\
\hline
\end{tabular}

${ }^{\text {a }}$ See Table 1 for the list of these questions.

b DIS = Distance of respondents' residence from the main road; TOW, Respondents' township affiliation; GEN, Gender; EDU, Education; AGE, Age; HHS, Household size; LAND, Acreage of land owned per capita in respondents' household.

(Zhuge, 2000). Moreover, there is no clear provision to justify or require local participation in the country's Nature Reserve Ordinance (Jim et al., 2002). This problem is not unique to WBR because it is also found in other areas and countries (Trakolis, 2001; Jim et al., 2002; Rao et al., 2003).

\subsection{Attitudes, perceptions and two potential conflicts relevant to forest conservation}

Although most people had a positive attitude and admitted that WBR had brought them some benefits, they were not optimistic considering future people-park relationships and biodiversity conservation. Most respondents pointed out that compensation for cultivated land conversion into forests was not paid on time, and economic incentives for the Natural Forest Protection Project were reduced compared with two years ago. In informal discussions, they complained that the managers of WBR cared only about the Giant Panda rather than local people's development. They were very concerned about employment opportunities in the reserve. However, those from outside WBR took most of the limited employment opportunities in the reserve. This problem was also recognized in the evaluation of WBR's functions in Lu's study (Lu et al., 2003), which indicated that the function of Giant Panda protection was effective but the functions of environmental education, social development and economic development were marginalized. If local people's interest were marginalized for a long period, they might adopt actions detrimental to the goal of conservation (Maikhuri et al., 2001).

Male respondents have more supportive attitudes than females. Such a situation seems to be common elsewhere (Mehta and Heinen, 2001; Bandara and Tisdell, 2003). 
A possible explanation could be that, being housewives, female respondents paid more attention to living conditions. The policy of Switch from Fuelwood to Electricity brought more inconveniences to them than to males. Furthermore, scant knowledge and information also contributed to this discrepancy. The fact that respondents in Wolong Township are more dissatisfied with the reserve's policy may be caused by the reserve's policy of functional zonation. Human activities are limited in experimental zone and no human activity is allowed in the core zone. People in Wolong Township suffer more losses and limitations because suitable habitat for Giant Panda is distributed extensively in Wolong Township, and human activities are limited to a narrow space.

Respondents with higher education level expressed an objective opinion about the reserve: it brought both benefits and losses. They perceived more benefits because they had better environmental awareness and advantages in the reserve. In WBR, conservation education courses are set in schools to generate environmental awareness and interest in conservation among students. In addition, those who receive higher education have advantages and more opportunities to get a job inside and outside the WBR. Education is often considered to be an initial step in improving people's attitudes towards conservation, which is also reported in other studies (Newmark et al., 1993; Fiallo and Jacobson, 1995; Gillingham and Lee, 1999; Mehta and Heinen, 2001; Bandara and Tisdell, 2003). They also perceived losses brought by the reserve because of restrictions on natural resource utilization and limitations on human activities.

Combining local people's perceptions with WBR management and biodiversity conservation, we identified two potential conflicts by an in-depth analysis of three forest policies and local people's socioeconomic status.

The first potential conflict is derived from the decrease in cropland holding versus oversupply of the labor force. Because of the program of converting cultivated land into forests, cropland holdings of local people have decreased greatly. According to our investigation, the cultivated land per capita in a household varied from 0.005 to 0.117 ha, with an average of 0.039 ha (Wolong Nature Reserve Administration Bureau, 2002). Many labor forces were released from agricultural practices. However, people from outside WBR take most of the jobs in WBR, including maintenance of small hydropower stations, restaurant businesses, and management in the Bureau of Wolong Administration, because local people have no advantage in capital, technology, experience, and education. Some other jobs, such as transportation, forest guarding and housing construction are temporary and limited, and only those with certain qualifications can get them. In WBR, the number of laborers in the family and cropland holding have a great effect on household income due to limitations on mechanization of farming and employment opportunities. Therefore, household size and cropland holding were examined as significant factors affecting local people's perceived benefits and costs. Local excess labor forces have to collect resources for household use or sale to supplement the household income (Fu et al., 2004). IIED has suggested that employment opportunities lower the incentive to utilize wildlife illegally (IIED, 1994). Furthermore, due to the abundant supply of labor forces, local people may still continue some destructive activities even if there is development support by 'contracting' incremental income from new livelihoods out to the under-employed (Ferrare and Kramer, 1995). Therefore, oversupply of the labor force and limited job opportunities in WBR are potential threats to biodiversity conservation and challenges to WBR management.

The second potential conflict results from the Switch from Fuelwood to Electricity and the Natural Forest Protection Project. In WBR, with prohibition of fuelwood collection and the switch to electricity being carried out compulsively, the price of electricity became the focus of the conflict. The cost of electricity increased from 0.08 to 0.18 yuan $/ \mathrm{kWh}$ in recent years, though it had been suggested that the electricity price should be lowered to encourage local residents to switch from fuelwood to electricity (An et al., 2002). In the local people's perspective, economic incentives for the Natural Forest Protection Project subsidized their expenditures for electricity; however the economic incentives had decreased compared to two years ago. Many respondents stated that if electricity prices kept rising and economic incentives for the Natural Forest Protection Project continued to decline, they couldn't afford the electricity and would have to use the forest again for fuelwood sooner or later. Furthermore, the Natural Forest Protection Project, which is viewed as a community-based conservation approach to promote local people's participation and realize co-management, will be threatened too.

\subsection{Differentiation in reactions to policy scenarios}

At the local level, conflicts and incompatibilities between local people and protected areas have always been driven by economic necessity and lack of alternatives for local people (Rao et al., 2002). In WBR, because of the rapid increase in population, especially the rate of increase in the labor force, which was three times higher than the rate of change in the total population, ecological degradation of the Giant Panda's habitat occurred (Liu et al., 1999b, 2001). Therefore, a clear understanding of local people's responses to conservation through various management policies is necessary.

The relocation policy, which was put forward in the Planning Program of Wolong Nature Reserve (Wolong Nature Reserve Administration Bureau, 1998), was previously put into practice in WBR, but failed. In the early 1980s, the World Food Program and the Chinese government built a large apartment complex in order to encourage local residents to leave the core zones of the Giant Panda 
habitat. However, no household was willing to move into the complex. The research results showed that respondents residing far from the main road were more willing to relocate than those near the road. In our investigation, it was found that those living far from the road had difficulties in delivering their cabbage to the market in time with a competitive price due to poor transportation. This finding is different from Liu's survey results (Liu et al., 1999a), which found that most of the young people were willing to settle outside of the reserve before they got married. In group discussions, most respondents who were reluctant to relocate had doubts about their future in a strange place, especially whether they could acquire enough cropland or a job to raise their family.

Specifically, most respondents could accept the continuation of agriculture (with cash crop replacement) and tourism enterprises because they had obtained or seen tangible benefits from two cases. Eco-tourism in WBR is still at its initial stage and the revenues generated from tourism seldom go to local farmers, because the business is limited and dominated by those people from outside WBR. However, local people held high expectations for tourism development. They believed that it would eventually bring job opportunities to them because they had seen the rapid development of tourism in other locations near WBR, such as Jiuzhaigou Nature Reserve where local people had obtained revenues from tourism. The fact that different inclinations existed among respondents with different genders and household sizes could also be explained by the information acquired by the respondents. A review of the Eco-tourism Planning of Wolong Nature Reserve (Wolong Nature Reserve Administration Bureau and Forest Agency of Sichuan Province, 2002) showed that local community's benefits had been taken into consideration. However, no specific measures had been taken so far to develop an effective program. In group discussions, respondents expressed their concerns over two cases. In terms of cash crops, they were affected greatly by the fluctuation in cabbage price and lack of market competition. For those interested in eco-tourism, lack of start-up capital and experience might hinder their involvement in the ecotourism industry.

Acreage of land owned per capita in respondents' households plays a significant role in predicting local people's reactions to the cases of continuation of agriculture (with cash crop replacement) and continuation with the present system. A reasonable explanation is local people's income composition. In WBR, sale of cabbage is the main income source of local farmers and cabbage income has a significant positive relationship with the acreage of cabbage fields. Therefore, it is understandable that acreage of land owned per capita in respondents' households determines their reactions to the two policy scenarios. But income from cash crops varies greatly due to fluctuation in the price of cabbage outside the reserve, and conservative older respondents are unwilling to accept this scenario.

\section{Conclusion}

Social research in protected areas is expected to probe into local people's perceptions and advance the harmonious development of nature conservation and benefits to local people. This study may offer some valuable information that can be incorporated into decision-making and lead to resolution of the conflicts in WBR.

Poor communication and local participation in the reserve management result in scant knowledge and uneven information distribution among local people. A two-way communication mechanism should be established to provide information and interpretation to expose local people to the management of the reserve. Gender, residence location, household size, acreage of land owned and education have close associations with local people's attitudes. Management authorities have to take into account the heterogeneous characteristics of local people when establishing and implementing conservation policies.

In order to mitigate potential conflicts between the reserve and local people, it is urgent to develop employment opportunities for local people and establish a reasonable price and compensation mechanisms for local electricity expenditures. Otherwise, three policies relevant to forest conservation will not be able to achieve their intended purposes. The cost of electricity should be limited within local people's bearing capacities. Multiple measures, including providing start-up funding and technology training and improving education level should be taken to develop employment opportunities. Especially, improving the educational level of local people would help to mitigate current and potential conflicts by improving their knowledge and technical skills.

A relocation policy should be implemented step by step. Given the failed experience in implementing the relocation policy and the corresponding research results, the management authority should reconsider its applicability. It is not a viable expectation to have the entire local population settled outside the reserve at one time. However, it is feasible to relocate young people and those residing far from the road. Also some examples and reasonable policies concerning relocation should be presented to the local people to enhance their confidence.

\section{Acknowledgements}

This research is supported by the State Key Basic Research and Development Program of China (G2000046807) and the National Natural Science Foundation of China (40321101, 30300052). We thank Shuang Yang for her assistance in data collection. We are grateful to Mr Wang James and Doctor Madhur Anand for their help in English improvement. 


\section{References}

Agrawal, A., Gibson, C., 1999. Enchantment and disenchantment: the role of community in natural resource conservation. World Development 27 (4), 629-649.

An, L., Lupi, F., Liu, J., Linderman, M., Huang, J., 2002. Modeling the choice to switch from fuelwood to electricity: implication for giant panda habitat conservation. Ecological Economics 42, 445-457.

Bandara, R., Tisdell, C., 2003. Comparison of rural and urban attitudes to the conservation of Asian elephant in Sri Lanka: empirical evidence. Biological Conservation 110, 327-342.

Coggins, C.R., 2000. Wildlife conservation and bamboo management in China's southeast upland. The Geographical Review 90 (1), 83-111.

Ferrare, P.J., Kramer, R., 1995. A framework for affecting household behaviour to promote biodiversity conservation. USAID, Bureau for Africa.

Fiallo, E.A., Jacobson, S.K., 1995. Local communities and protected areas: attitude of rural residence towards conservation and Machalilla National Park, Ecuador. Environmental Conservation 22, 241-249.

Fu, B., Wang, K., Lu, Y., Liu, S., Ma, K., Chen, L., Liu, G., 2004. Entangling the complexity of protected area management: the case of Wolong Biosphere Reserve, Southwestern China. Environmental Management 33 (6), 788-798.

Geoghegan, T., Renard, Y., 2002. Beyond community involvement: lessons from the insular Caribbean. Parks 12 (2), 16-27.

Gillingham, S., Lee, P.C., 1999. The impact of wildlife related benefits on the conservation attitude of local people around the Selous game reserve, Tanzania. Environmental Conservation 26, 218-228.

Han, N., 2000. A policy study on sustainable management for China's nature reserves. Journal of Nature Resource (in Chinese) 15 (3), 201207.

Harkness, J., 1998. Recent trends in forestry and conservation of biodiversity in China. The China Quarterly 156, 911-934.

IIED, 1994. Whose eden? an overview of community approach to wildlife management. IIED, Nottingham, UK, chapter 4.

IUCN, 1993. Parks for life. Report of the th world congress on national parks and protected areas. IUCN, Gland, Switzerland. p. 252.

Jim, C.Y., Steve, S.W., XU, 2002. Stifled stakeholders and subdued participation: interpreting local responses toward Shimentai Nature Reserve in South China. Environmental Management 30 (3), 327-341.

Liu, J., Ouyang, Z., Tan, Y., Yang, J., Zhang, H., 1999a. Changes in human population structure and implication for biodiversity conservation. Population and Environment 21, 46-58.

Liu, J., Ouyang, Z., Taylor, W.W., Group, R., Tan, Y., Zhang, H., 1999b. A framework for evaluating the effects of human factors on wildlife habitat: the case of Giant Pandas. Conservation Biology 13, 1360-1370.

Liu, J., Linderman, M., Ouyang, Z., An, L., Zhang, H., 2001. Ecological degradation in protected areas: the case of wolong nature reserve for giant pandas. Science 292 (6), 98-101.

Liu, J., Ouyang, Z., Pimm, S.L., Raven, P.H., Wang, X., Miao, H., Han, N., 2003. Protecting china's biodiversity. Science 300 (23), 1240-1241.

Lu, Y., Chen, L., Fu, B., Liu, S., 2003. A framework for evaluating the effectiveness of protected areas: the case of Wolong Biosphere Reserve. Landscape and Urban Planning 967, 1-11.

Maikhuri, R.K., Nautiyal, S., Rao, K.S., Saxena, K.G., 2001. Consevation policy-people conflicts: a case study from Nanda Devi Biosphere Reserve,India. Forest Policy and Economics 2, 355-365.

McNeely, J.A., 1990. The future of national parks. Environment 32 (1), 1620 see also pages $36-41$.
Mehta, J.N., Heinen, J.T., 2001. Does community-based conservation shape favorable attitudes among locals? an empirical study from Nepal. Environmental Management 28 (2), 165-177.

Miao, H., 2000. Community participation mechanism of china's nature reserve. In: China Man and Biosphere Committee (Eds), Study of Sustainable Management Policies for China's Nature reserve (in Chinese). Scientific and Technical Documents Publishing House, Beijing, pp. 57-71.

Newmark, W.D., Leonard, N.L., Sariko, H.I., Gamassa, D.G.M., 1993. Conservation attitudes of local people living adjacent to five protected areas in Tanzania. Biological Conservation 63, 177-183.

Ouyang, Z., Wang, X., Miao, H., Han, N., 2002. Problems of management system of China's nature preservation zones and their solution (in Chinese). Science and Technology Review 1, 49-52.

Rao, K.S., Maikhuri, R.K., Saxena, K.G., 2003. Local people's knowledge, aptitude and perceptions of planning and management issues in Nanda Devi Biosphere Reserve, India. Environmental Management 31 (2), $168-181$.

Rao, M., Rabinowitz, A., Khaing, S.T., 2002. Status review of the protected-area system in Myanmar, with recommendations for conservation planning. Conservation Biology 16 (2), 360-368.

Ruchi, B., 1998. Attitudes of local people toward conservation and alternatives to forest resources: a case study from the lower Himalayas. Biodiversity and Conservation 7, 1245-1259.

Sewell, W.R.D., 1973. Broadening the approach to evaluation in resource management decision-making. Journal of Environmental Management $1,33-60$.

Streever, W.J., Perry, M.C., Searles, A., Stevens, T., Svoboda, P., 1998 Public attitudes and values for wetland conservation in New SouthWales, Australia. Journal of Environmental Management 54, $1-14$.

Trakolis, D., 2001. Local people's perceptions of planning and management issues in prespes lakes national park, Greece. Journal of Environmental Management 61, 227-241.

White, G.F., 1966. Formation and role of public attitudes. In: Jarrett, H. (Ed.), Environmental Quality in a Growing Economy. John Hopkins Press, Baltimore, p. 105.

Wolong Nature Reserve Administration Bureau, (1998). General planning of Wolong Nature Reserve Official report (in Chinese).

Wolong Nature Reserve Administration Bureau, (2001). Implementary Scheme of Natural Forest Protection Project Official document (in Chinese).

Wolong Nature Reserve Administration Bureau, (2002). Statistical data of rural cooperative economic of Wolong Special Zone in 2002 official document (in Chinese).

Wolong Nature Reserve Administration Bureau, (2002). Forest Agency of Sichuan Province, Ecotourism Planning of Wolong National Nature Reserve (2002-2005) official report (in Chinese).

Wu, X., Xu, H., Jiang, M., Liu, L., 2002. Harmonized development of nature reserve and local community. Rural Eco-Environment (in Chinese) 18 (2), 10-13.

Zhuge, R., 2000. Questionnaire survey on local participation into efforts of nature conservation and resources management in nature reserve of China. In: China Man and Biosphere Committee (Eds), Study of Sustainable Management Policies for China's Nature reserve (in Chinese). Scientific and Technical Documents Publishing House, Beijing, pp. 131-137.

State Forestry Administration. 2001. www.wildlife-plant.gov.cn/en/index. htm. 